\title{
Pesan-Pesan Kemanusiaan Novel Jenghis Khan Karya John Man: Pendekatan Struktural Genetik
}

\author{
Tri Budianingsih \\ Program Studi Sastra China, Fakultas Sastra \\ Universitas Al Azhar Indonesia, Jl. Sisingamangaraja, Jakarta 12110 \\ Penulis untuk korespondensi/E-mail: tri.budianingsih@uai.ac.id
}

\begin{abstract}
Abstrak - Penelitian ini mengenai pesan-pesan kemanusiaan pada novel Jenghis Khan sebuah kisah yang diangkat dari negeri Mongolia karya seorang penulis barat yang bernama John Man. Penelitian ini adalah penelitian kualitatif dengan pendekatan struktural genetik. Tujuan dari penelitian ini dilakukan untuk mengetahui sisi baik dari seorang panglima besar yang terkenal dan ditakuti di penjuru dunia dalam masanya. Metode yang digunakan dalam penelitian ini menggunakan pendekatan kualitatif dengan metode analisis isi model induktif. Dalam analisis isi kualitatif, seharusnya ditentukan apa bagian penarikan kesimpulan dari informasi yang dibuat, kepada aspek-aspek komunikator (pengalaman, pendapat dan perasaannya). Hasil penelitian menunjukkan dalam novel Jenghis Khan Karya John Man terdapat 16 informasi yang menunjukkan nilai-nilai kemanusiaan sang tokoh terhadap pesanpesan kemanusiaan, kepedulian dan toleransi berjumlah 5 dengan presentasi $31 \%$, kegotongroyongan dan harapan berjumlah 3 dengan presentasi $19 \%$.
\end{abstract}

\section{Kata Kunci - Novel, Pesan Kemanusiaan, Struktural Genetik}

Abstract - This research is about the messages and humanity in the novel Genghis Khan, a story lifted from Mongolia by a writer named John Man. This study is a qualitative research with a genetic structural approach. The purpose of this study was conducted to determine the good side of a great commander known and feared throughout the world in his time. The method used in this study used a qualitative approach with the method of inductive content analysis models. In a qualitative content analysis, it should be determined what part inference of created information to the aspects of the communicator (thoughts, opinions and feelings). The results showed on Genghis Khan novel by John Man, there are 16 information that shows the values of humanity of the hero to the messages of humanity, caring and tolerance amounts 5 with $31 \%$ presentation, mutual cooperation and hope totaling 3 with $19 \%$ presentation.

Keywords - Novel, Messages of Humanity, Structural Genetic

\section{PENDAHULUAN}

Latar Belakang

$\mathrm{D}$ engan membaca karya satra pembaca dapat menjadi manusia yang berbudaya (cultured man). Manusia berbudaya adalah manusia yang responsif terhadap apa-apa luhur dalam hidup ini. Manusia yang demikian itu selalu mencari nilainilai kebenaran, keindahan dan kebaikan (Jacob
Sumardjo dan Saini KM,(1986: 11)). Untuk mengetahui nilai-nilai kebenaran dan keindahan yang terkandung dalam karya satra perlu dilakukan upaya pengkajian melalui apresiasi sastra.

Apresiasi satra adalah kegiatan menggali karya sastra secara sungguh-sungguh sehingga menumbuhkan pengertian, pengharapan, kepekaan pikiran kritis, dan kepekaan perasaan yang baik 
terhadap karya sastra (Jacob Sumardjo dan Saini KM, (1986: hal 9)).

Kegiatan mengapresiasi sastra dalam arti menikmati keindahannya, menghayati nilai-nilai yang terkandung di dalamnya, serta memperoleh manfaat bagi kehidupan kita, dapat terlaksana apabila kita secara langsung membacanya atau mendengarkan karya sastra. Oleh karena itu, sangatlah dianjurkan agar kita membaca karya sastra (Imam Syafie, 1990: 197).

Dengan sastra, kita akan mendapat penghiburan dan kontemplasi juga dapat memberikan informasi dan pilihan-pilihan yang bermatra moral. Memang dalam hal ini sastra tidak menawarkan alternatif hitam-putih, benar-salah, dan baik-buruk. Tapi sastra dapat memberi inspirasi untuk mendengar, memahami dan menyikapi masalah untuk diambil hikmahnya (Suroso. 2005: 105).

John Man, bermukim di London, adalah sejarawan dan travel writer dengan minat khusus ihwal Mongolia. Setelah menyelesaikan studi mengenai Jerman dan Prancis di Oxford, ia mengambil dua program sekolah pascasarjana: kajian sejarah sains di Oxford dan studi bangsa Mongol pada School of Oriental and African Studies di London. Karyanya, Gobi: Tracking the Desert, adalah buku pertama tentang topik tersebut sejak 1920-an. Ia juga pengarang Atlas of the Year 1000, sebuah potret dunia pada pergantian milenium; Alpha Beta, tentang awal mula alfabet; The Gutenberg Revolution, sebuah telaah tentang asal-usul dan dampak percetakan; The Great Wall, buku sejarah mengenai situs keajaiban dunia di China, Tembok Besar; dan The Leadership Secrets of Jenghis Khan, prinsip dan rahasia sukses kepemimpinan Jenghis Khan. Selain itu, John Man juga menulis Jenghis Khan, Kublai Khan, dan Attila the Hunketiganya buku mengenai biografi tokoh legendaris dalam sejarah kekaisaran kuno. Berkat karya-karya itu, John Man dengan cepat menjadi salah satu sejarawan dunia yang tulisannya paling banyak dibaca

(http://www.bukabuku.com/authorscorner/detail/ 2012/john-man.html).

Novel Jenghis Khan adalah cerita legenda sang penakluk dari Mongolia dan legenda sang penguasa terbesar dalam sejarah. Jenghis Khan, sang penakluk dari Mongolia. Di masa kini, Jenghis Khan kerap dianggap momok, pahlawan, dan manusia setengah dewa. Bagi umat muslim, bangsa
Rusia dan Eropa, dia adalah seorang pembunuh massal. Namun di tanah kelahirannya, bangsa Mongol memujanya sebagai bapak bangsa; bangsa Cina menghormatinya sebagai pendiri dinasti; dan di kedua Negara tersebut para pemuja mencari berkahnya. Peneliti tertarik untuk mengkaji novel Jenghis Khan karya John Man ini: (a) dari segi pesan-pesan kemanusiaan dari sudut mata orang Mongolia yang ingin disampaikan oleh pengarangnya tersebut kepada pembaca, karena John Man menggunakan pengalaman langsung guna menyingkap pengaruh sang Khan yang terus lestari. (b) merupakan novel nasional best seller, tapi juga di Internasional karena banyak para pembaca dari berbagai negara yang memuji novel ini;

Peneliti menganalisis berdasarkan tinjauan struktural genetik karena terkait dengan sejarah dan masyarakat yang melingkupi penciptaan karya sastra. Kajian struktural genetik tersebut meliputi kajian latar belakang sejarah dan sosial budaya, serta pandangan dunia pengarangnya.

\section{Identifikasi Masalah}

Berdasarkan latar belakang masalah tersebut maka dapat disusun kemungkinan-kemungkinan masalah yang timbul, yaitu:

1. bagaimana struktur intrinsik novel (tema, tokoh dan penokohan, latar, sudut pandang dan amanat) yang membangun novel Jenghis Khan?

2. adakah pesan-pesan kemanusiaan dari sudut pandang orang Mongolia yang disampaikan pengarang dalam novel Jenghis Khan?

3. mengapa pengarang mengungkapkan pesanpesan kemanusiaan dari sudut pandang orang Mongolia dalam novelnya?

4. bagaimana pengarang mengungkapkan nilainilai kemanusiaan dalam novel Jenghis Khan?

5. bagaimana latar belakang sejarah dan sosial budaya dalam novel tersebut?

\section{Perumusan Masalah}

Berdasarkan identifikasi masalah di atas, perumusan masalah ini adalah bagaimana John Man mengungkapkan pesan-pesan kemanusiaan dari sudut pandang orang Mongolia dalam novelnya Jenghis Khan ditinjau secara struktural genetik?

\section{Tujuan Penelitian}

Berdasarkan perumusan masalah di atas, penelitian ini bertujuan untuk memperoleh pemahaman tentang pengungkapan pesan-pesan kemanusiaan yang disampaikan oleh pengarangnya dari sudut 
pandang orang Mongolia dalam rangka memperjuangkan martabat manusia dan untuk mendapatkan gambaran yang jelas tentang aspek pesan-pesan itu dalam novel Jenghis Khan. Lebih jauh, peneliti ini bertujuan untuk: (1) mengungkapkan bentuk pesan-pesan kemanusiaan secara intrinsik, yakni melalui bahasa dalam novel Jenghis Khan; (2) mengungkapkan pesan-pesan kemanusiaan dalam novel Jenghis Khan secara ekstrinsik melalui pendekatan sosiologi sastra, dan pendekatan psikologi sastra.

\section{Manfaat Penelitian}

Hasil penelitian ini diharapkan memberikan sejumlah manfaat atau kegunaan, antara lain:

1. secara teoretis/akademis, hasil penelitian ini diharapkan dapat (a) memperkaya khasanah kepustakaan di bidang sastra, khususnya mengenai kesastraan Cina dan prosa terjemahan; (b) menjadi bahan masukan bagi mereka yang berminat untuk menindaklanjuti penelitian ini dengan pendekatan yang berbeda.

2. Secara praktis, hasil penelitian ini diharapkan dapat berguna bagi:

- peneliti sendiri, untuk menambah pengetahuan dan wawasan tentang pesanpesan kemanusiaan yang disampaikan melalui karya sastra sehubungan dengan terjadinya dehumanisasi di tengah masyarakat;

- para pengajar mata kuliah yang berkaitan dengan kesustraan Cina dan prosa terjemahan, untuk dapat memotivasi mahasiswanya agar lebih menghargai dan mencintai karya sastra;

- para mahasiswa, terutama mahasiswa jurusan Sastra Cina dan prosa terjemahan agar dapat memahami dan memiliki apresiasi terhadap karya sastra khususnya yang bertemakan kemanusiaan;

- masyarakat pembaca, khususnya generasi muda agar dalam rangka pengembangan minat untuk gemar membaca karya sastra, sehingga timbul rasa penghargaannya terhadap karya sastra dan kepeduliannya terhadap kehidupan manusia.

\section{KAJIAN TEORETIS}

Bagian ini membahas teori yang digunakan dalam melakukan penelitian. Adapun teori yang dikemukakan meliputi hakikat novel yang mencakup pengertian dan struktur novel (seperti tema, tokoh dan penokohan, latar, sudut pandang dan amanat), serta hakikat pesan-pesan kemanusiaannya, melalui, pendekatan sastra struktural genetik. Melalui acuan teoretis dalam bagian ini, peneliti berusaha menganalisis struktur intrinsik dan ekstrinsik novel sekaligus.

\section{Pengertian Novel}

Novel merupakan karya fiksi yang mengungkapkan aspek-aspek kemanusiaan yang lebih mendalam dan disajikan dengan halus (M. Atar Semi, 1993: 32). Novel di Indonesia secara "resmi" muncul setelah terbitnya buku Si Jamin dan Si Johan, tahun 1919, oleh Marari Siregar, yang merupakan novel saduran dari novel Belanda. Kemudian pada tahun berikutnya terbit novel Azab dan Sengsara oleh pengarang yang sama. Sejak itu mulailah berkembang sastra fiksi yang dinamai novel ini dalam khazanah sastra Indonesia (M. Atar Semi, 1993: 33).

\section{Struktur Novel}

Novel sebagai sebuah karya fiksi yang ditulis oleh pengarangnya berdasarkan kehidupan yang nyata, memiliki struktur yang dibangun melalui berbagai unsur seperti peristiwa, tokoh, alur, latar, sudut pandang, dan lain-lain.

\section{a. Tokoh dan Penokohan}

Tokoh cerita menempati posisi strategis sebagai pembawa dan penyampai pesan, amanat, moral, atau sesuatu yang sengaja ingin disampaikan kepada pembaca. Tokoh-tokoh cerita dalam fiksi adalah tokoh rekaan yang tak pernah ada di dunia nyata. Tetapi, dalam karya tertentu, sering juga terdapat adanya tokoh-tokoh sejarah tertentu--artinya tokoh manusia nyata, bukan rekaan pengarang yang muncul dalam cerita, bahkan mungkin mempengaruhi plot (Burhan Nurgiyantoro, 1995: 167).

Teknik ekspositori atau yang disebut juga teknik analitis memberikan deskripsi, uraian atau penjelasan pelukisan tokoh cerita secara langsung; sedangkan untuk teknik dramatik, pengarang tidak mendeskripsikan secara eksplisit sifat dan sikap serta tingkah laku tokoh (Nurgiyantoro, 1995: 195198).

Tokoh dan penokohan merupakan unsur yang penting dalam karya naratif (Burhan Nurgiyantoro, 1995: 164). Tokoh merupakan pelaku yang mengemban peristiwa dalam cerita fiksi sehingga peristiwa itu mampu menjalin suatu cerita, sedangkan istilah "penokohan" lebih luas 
pengertiannya dari pada "tokoh" dan "perwatakan", sebab ia sekaligus mencakup masalah siapa tokoh cerita, bagaimana perwatakan, dan bagaimana penempatan dan pelukisannya dalam sebuah cerita sehingga sanggup memberikan gambaran yang jelas kepada pembaca (Burhan Nurgiyantoro, 1995: 166).

Tokoh-tokoh cerita dalam sebuah fiksi dapat dibedakan ke dalam beberapa jenis penamaan berdasarkan dari sudut mana penamaan itu dilakukan. dalam hal ini peneliti hanya menjelaskan tokoh secara lingkup dasar mencakup 3 kategori; 1 . tokoh protagonis, 2. tokoh bawahan dan 3. tokoh sederhana.

Tokoh yang memegang peran pemimpin disebut tokoh utama atau protagonis (Sudjiman, 1986: 61). Tokoh utama atau tokoh protagonis adalah tokoh yang diutamakan penceritaannya dalam novel tersebut. Ia merupakan yang paling banyak diceritakan, ia juga bahkan menjadi pusat sorotan dalam kisahan. Kriterium yang digunakan untuk menentukan tokoh utama bukan frekensi kemunculan tokoh itu di dalam cerita, melainkan intensitas keterlibatan tokoh dalam peristiwaperistiwa yang membangun cerita (Panuti Sudjiman, 1988: 16).

Menurut Grimes, seperti diuraikan Panuti Sudjiman, tokoh bawahan adalah tokoh yang tidak sentral kedudukannya di dalam cerita tetapi kehadirannya sangat diperlukan untuk menunjang tokoh utama (Panuti Sudjiman, 1988: 19).

Menurut Nurgiyanto, tokoh sederhana, dalam bentuknya yang asli, adalah tokoh yang hanya memiliki satu kualitas pribadi tertentu, satu sifatwatak yang tertentu saja. Sebagai seorang tokoh manusia, ia tidak diungkapkan berbagai kemungkinan sisi kehidupannya. Ia memiliki sifat dan tingkah laku yang dapat memberikan efek kejutan bagi pembaca. Sifat dan tingkah laku seorang tokoh sederhana bersifat monoton (Burhan Nurgiyantoro, 1995: 181-182).

\section{b. Latar}

Latar atau setting yang disebut juga sebagai landas tumpu, menyaran pada pengertian tempat, hubungan waktu dan lingkungan sosial tempat terjadinya peristiwa-peristiwa yang diceritakan (Abrams, $1981:$ 175).

Unsur latar dapat dibedakan ke dalam tiga unsur pokok, yaitu tempat, waktu, dan sosial.
Latar tempat menyaran pada lokasi terjadinya peristiwa yang diceritakan dalam sebuah karya fiksi. Latar tempat dalam novel meliputi berbagai lokasi, dan terus berpindah-pindah dari satu tempat ke tempat lain sesuai dengan perkembangan plot dan perjalanan tokoh (Nurgiyantoro, 1995: 229).

Latar waktu berhubungan dengan masalah "kapan" terjadinya peristiwa-peristiwa yang diceritakan dalam sebuah karya fiksi. Masalah "kapan" tersebut biasanya dihubungkan dengan waktu faktual, waktu yang ada kaitannya atau dapat dikaitkan dengan peristiwa sejarah.

Latar sosial menyaran pada hal-hal yang berhubungan dengan perilaku kehidupan sosial masyarakat di suatu tempat yang diceritakan dalam karya fiksi. Tata cara kehidupan sosial masyarakat mencakup berbagai masalah dalam lingkup yang cukup kompleks. Ia dapat berupa kebiasaan hidup, adat istiadat, tradisi, keyakinan, pandangan hidup, cara berpikir dan bersikap, dan lain-lain (Nurgiyantoro, 1995: 227-234).

Lebih lanjut menurut Nurgiyantoro, latar atmosfer merupakan deskripsi kondisi latar yang mampu menciptakan suasana tertentu, seperti suasana ceria, romantis, sediih, muram, maut, misteri, dan sebagainya (Nurgiyantoro, 1995: 243).

c. Alur

Menurut Aminuddin, alur adalah rangkaian cerita yang dibentuk oleh tahapan-tahapan peristiwa sehingga menjalin suatu cerita yang dihadirkan oleh para pelaku dalam suatu cerita (Aminuddin, 1987: 9); sedangkan menurut Luxemburg, alur adalah konstruksi yang dibuat pembaca mengenai sebuah deretan peristiwa yang secara logik dan kronologik saling berkaitan dan yang diakibatkan atau dialami oleh para pelaku (Jan van Luxemburg dkk., (1991: 149)).

Untuk menganalisis alur, ada beberapa tahapan alur yang dibedakan menjadi lima bagian. Berikut ini adalah tahapan yang telah dikemukakan oleh Tasrif (Burhan Nurgiyantoro, 1995: 149-150):

- Tahap situation (tahap penyituasian)

- Tahap generating circumstances (tahap pemunculan konflik)

- Tahap rising action (tahap peningkatan konflik)

- Tahap climax (tahap klimaks)

- Tahap denouement (tahap penyelesaian)

(Burhan Nurgiyantoro, 1995: 149-150). 
Berdasarkan uraian mengenai tahap alur, ada yang perlu dicatat dan dipahami bahwa menurut Pickering dan Hoeper (James H. Pickering dan Jeffry D. Hoeper, (1981: 16)) kebanyakan alur dapat mengandung lebih dari satu konflik. Beberapa konflik ini sebenarnya tidak pernah disampaikan secara eksplisit oleh pengarang atau tokoh cerita dan seharusnya diduga oleh pembaca melalui apa yang dilakukan atau dikatakan oleh tokoh cerita ketika alur terungkap. Konflik adalah dasar adanya pertentangan atau tegangan yang mengatur alur sebuah novel dalam gerakan, memikat pembaca, membangun rasa ingin tahu atau misteri dan membangkitkan harapan untuk setiap peristiwa yang mengikutinya.

Alur dikatakan progresif apabila tahapannya seperti yang telah dikemukakan oleh peneliti di atas dikisahkan bersifat kronologis secara runtun, yaitu:

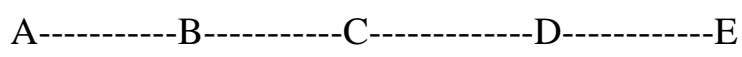
$\mathrm{A}=$ tahap penyituasian
$\mathrm{B}=$ tahap pemunculan konflik
$\mathrm{C}=$ tahap peningkatan konflik
$\mathrm{D}=$ tahap klimaks
$\mathrm{E}=$ tahap penyelesaian

Alur dikatakan regresif apabila tahapannya tidak bersifat kronologis, jadi cerita tidak dimulai dari tahap awal, melainkan mungkin dari tahap tengah atau bahkan tahap akhir. Dengan begitu novel yang memiliki alur dengan jenis ini, dapat langsung menyuguhkan adegan klimaks kepada pembacanya. Berikut adalah skemanya :

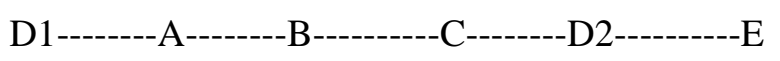
$\mathrm{A}=$ tahap penyituasian
$\mathrm{B}=$ tahap pemunculan konflik
$\mathrm{C}=$ tahap peningkatan konflik
D1 = tahap klimaks
$\mathrm{D} 2=$ tahap klimaks
$\mathrm{E}=$ tahap penyelesaian

Tidak tertutup kemungkinan apabila ada alur yang terdiri dari alur progresif dan regresif. Alur seperti ini biasanya disebut dengan alur campuran yang di dalamnya sering terdapat adegan-adegan sorot balik. Dan skemanya sebagai berikut :

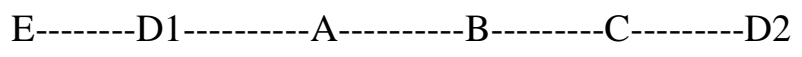
$\mathrm{A}=$ tahap penyituasian
$\mathrm{B}=$ tahap pemunculan konflik

$$
\begin{array}{lll}
\mathrm{C} & = & \text { tahap peningkatan konflik } \\
\mathrm{D} 1 & = & \text { tahap klimaks } \\
\mathrm{D} 2 & = & \text { tahap klimaks } \\
\mathrm{E} & = & \text { tahap penyelesaian }
\end{array}
$$

Diperjelas oleh Sudjiman, bahwa sorot balik ini dapat disampaikan dalam bentuk dialog, mimpi, lamunan, atau kenangan terhadap suatu peristiwa masa lalu. (Sudjiman, 1986: 33)

\section{d. Tema}

Tema (theme), menurut Stanton (1965: 88) dan Kenny (1966 : 20), adalah makna yang dikandung oleh sebuah cerita. Shipley dalam Dictionary of Word Literature (1962 : 417) mengartikan tema sebagai subjek wacana, topik umum, atau masalah utama yang dituangkan ke dalam cerita. Dalam hal ini Nurgiyantoro membedakannya ke dalam lima tingkatan berikut:

1) Tema tingkat fisik

2) Tema tingkat organik

3) Tema tingkat sosial

4) Tema tingkat egois

5) Tema tingkat divine

(Nurgiyantoro, 1995: 62-82)

\section{e. Amanat}

Menurut Sudjiman, amanat adalah suatu pesan atau ajaran moral yang ingin disampaikan oleh pengarang dari sebuah karya sastra. Jika permasalahan yang diajukan dalam cerita juga diberi jalan keluarnya oleh pengarang, maka jalan keluarnya itulah yang disebut dengan amanat. Amanat yang terdapat dalam karya sastra dapat disampaikan secara eksplisit maupun implisit. Implisit jika jalan keluarnya itu disiratkan dalam tingkah laku tokoh menjelang cerita berakhir; sedangkan eksplisit jika pengarang pada tengah atau akhir cerita menyampaikan seruan, saran, peringatan, nasihat, anjuran, larangan dan sebagainya berkenaan dengan gagasan yang mendasari cerita itu (Sudjiman,1986: 57-58).

\section{Hakikat Pendekatan Struktural Genetik}

Penelitian ini menggunakan pendekatan struktural genetik, yakni dengan memandang karya sastra dari dua sudut: intrinsik dan ekstrinsik. Menurut Endraswara, studi haruslah dimulai dari kajian unsur intrinsik untuk menemukan kesatuan dan koherensinya yang akan dijadikan sebagai data dasar. Selanjutnya, penelitian dilanjutkan dengan menghubungkannya dengan realitas masyarakatnya. Karya sastra dipandang sebagai refleksi zaman, yang dapat mengungkapkan aspek 
sosial, budaya, politik, ekonomi, dan psikologi (Suwardi Endraswara, 2003: 56-57).

Strukturalisme genetik (genetic structuralisme) adalah cabang penelitian sastra secara struktural yang tak murni. Penelitian strukturalisme genetik semula dikembangkan di Prancis atas jasa Lucien Goldmann. Dalam beberapa analisis novel, Goldmann selalu menekankan latar belakang sejarah. Hal itu dikarenakan teks sastra dapat sekaligus merepresentasikan kenyataan sejarah yang mengkondisikan munculnya karya sastra (Endraswara, 1995: 56).

\section{Jadi menurut Goldman:}

“Thus human realities are presetend as two-sided processes destructuration of old structurations and structuration of new totalities capable of creating equilibria capable of satisfying the new demands of the social groups that are elaborationg them.

From this point of view, the scientific study of human facts, whether economic, social, political, or cultural, involves an effort to elucidate these processes by uncovering both the equilibria that they are destryoing and those to wards which they are moving." (Lucien Goldmann, 1975: 156).

Menurut Teeuw, definisi struktur Goldmann yang telah disebutkan di atas praktis identik dengan Aristoteles (A. Teeuw, 1988: 153). Sejak jaman Yunani, Aristoteles telah mengenalkan strukturalisme dengan konsep: wholeness, unity, complecity, dan coherence. Hal ini menjelaskan bahwa keutuhan makna bergantung pada koherensi keseluruhan unsur sastra. Keseluruhan sangat berharga dibandingkan unsur yang berdiri sendiri (Suwardi Endraswara, 2003: 50).

\section{Pendekatan Struktural}

Teeuw mengatakan bahwa telaah sastra dengan pendekatan struktural hanya difokuskan pada teks semata. Karya sastra dianggap sebagai suatu totalitas yang otonom dan terlepas dari dunia lain. Untuk mendapatkan makna yang menyeluruh, penganalisisan karya sastra dengan metode ini adalah dengan membongkar dan memaparkan secermat, seteliti dan semendetil mungkin keterkaitan dan keterjalinan semua unsur dan aspek karya sastra (Andreas Teeuw, 1984: 135).

Menganalisis novel untuk kepentingan tujuan penelitian ini, yakni untuk mendapatkan gambaran yang jelas dari pesan-pesan kemanusiaan yang terdapat di dalam novel Jengis Khan, adalah dengan menganalisis unsur-unsur pokok yang terdapat di dalam karya fiksi, seperti yang telah diungkapkan
Taylor, yakni Analisis struktur cerita (action), analisis struktur tokoh, dan analisis struktur latar. Berdasarkan hasil ketiga struktur itulah nantinya ditemukan permasalahan pokok yang pada akhirnya melahirkan tema dan amanat. Dan, pada setiap bagian analisis akan ditampilkan kutipan-kutipan teks sesuai dengan keperluan.

Struktur cerita adalah rangkaian peristiwa demi peristiwa secara logis dan kronologis yang sebabkan oleh tindakan tokoh, sedangkan struktur penceritaan (alur) adalah susunan cerita sejak awal sampai akhir (Umar Junus, 1986: 77). Analisis sruktur cerita bertujuan untuk mendapatkan urutan peristiwa yang pada akhirnya dapat ditemukan konflik dan sekaligus diketahui pula tema.

Struktur tokoh, menurut Abrams adalah karakteristik setiap tokoh dan hubungannya dengan tokoh-tokoh lain. Analisis terhadap struktur tokoh dimulai dari tokoh utama dengan asumsi bahwa dalam novel hanya ada satu tokoh utama, kemudian dilanjutkan dengan tokoh-tokoh sampingan yang berhubungan dengan tokoh utama. Identifikasi tokoh dapat dilihat dengan nama, tampilan fisik, peran dan tingkah lakunya, termasuk perkataannya.

Struktur latar adalah kesatuan waktu, suasana terjadinya peristiwa atau tindakan. Kadang-kadang, latar tidak dihadirkan secara jelas, sering juga dengan isyarat-isyarat melalui suasana. Analisis struktur latar bertujuan untuk mendapatkan gambaran waktu, tempat, suasana, situasi psikologis dan moral masyarakat sehingga dapat melihat kewajaran posisi tingkah laku tokoh (MH. Abrams, 1971: 21).

\section{Pendekatan Struktural Genetik}

Sebagaimana yang dikemukakan oleh Wellek dan Warren, penelitian karya sastra pertama-tama haruslah dimulai dengan menganalisis aspek intristiknya, setelah itu baru dianalisis aspek ekstrinsiknya. Aspek intrinsik merupakan unsurunsur yang terdapat di dalam karya sastra, sedangkan aspek ekstrinsik merupakan hubungan antara karya sastra dengan faktor-faktor di luarnya. (Wellek dan Warren, h. 77). Ke dalamnya tercakup berbagai bentuk interaksi antar manusia yang dipengaruhi oleh nilai-nilai dan norma-norma. Salah satu bentuk nilai-nilai dan norma-norma itu adalah pesan-pesan kemanusiaan. Interaksi antar manusia adalah bagian dari social budaya. Oleh sebab itu, setelah dilakukan analisis struktur novel akan dilanjutkan dengan analisis sosiologis sastra dan psikologis sastra sebagai landasan teori aspek 
sosialbudaya, yakni dengan menggunakan pendekatan struktural genetik.

Goldmann sebagaimana dikutip Junus, memberikan rumusan penelitian strukturalisme genetik ke dalam tiga hal, yakni: (1) penelitian terhadap karya sastra seharusnya dilihat sebagai suatu kesatuan; (2) karya sastra yang diteliti seharusnya karya sastra yang bernilai sastra, yaitu karya sastra yang mengandung tegangan (tension) antara keragaman dalam kesatuan dan keseluruhan (a coherent whole); dan (3) dianalisis dengan latar belakang sosial. Sifat hubungan tersebut: (a) yang berhubungan latar belakang sosial adalah unsur kesatuan, (b) latar belakang yang dimaksud adalah pandangan dunia suatu kelompok sosial yang dilahirkan oleh pengarang sehingga hal tersebut dapat dikonkretkan. Pandangan dunia dalam sastra adalah kesadaran dalam dunia mungkin atau dengan perkataan lain, pandangan dunia yang terekspresi dalam karya sastra adalah pandangan dunia imajiner (Umar Junus, 1986: 26). Secara definitif, struktural genetik adalah analisis struktur dengan memberi perhatian terhadap asal-usul karya sastra. Hal itu diungkapkan Ratna bahwa struktural genetik memberikan perhatian pada analisis intrinsik dan ekstrinsik. Meski demikian, sebagai teori yang telah teruji validitasnya, struktural genetik masih perlu ditopang oleh teori-teori ilmu sosial dan pandangan dunia (Ratna, hal 123).

Secara sederhana, kerja penelitian struktural genetik dapat diformulasikan dalam tiga langkah. Pertama, penelitian bermula dari kajian intrinsik, secara parsial dan keseluruhan. Kedua, menelaah latar sosial budaya dan kesejarahan serta psikologi yang turut mengondisikan lahirnya karya sastra. Ketiga, mengaitkan dengan latar sosial budaya dan psikologi pengarang sebagai bagian dari komunitas tertentu. (Endraswara, hal 62)

\section{Pendekatan Sosiologi Sastra}

Menurut Umar Junus, karya sastra adalah cermin kehidupan atau cerminan masyarakat pada suatu masa dan suatu tempat; dengan kata lain, karya sastra adalah refleksi sosial (Junus, 1984: 57). Oleh sebab itu, di dalam karya sastra terkandung unsur realitas sosial di dalam masyarakat. Adanya hubungan sastra dengan masyarakat yang menghasilkannya itulah yang melahirkan teori-teori sastra. Umar Junus mengklasifikasikan sosiologi sastra sebagai: (1) karya sastra dilihat dari dokumen sosiobudaya, (2) penelitian mengenai penghasilan dan pemasaran sastra, (3) penelitian tentang sebabsebab penerimaan masyarakat terhadap sebuah karya sastra yang ditulis oleh penulis tertentu, (4) pengaruh sosiobudaya terhadap penciptaan karya sastra, (5) pendekatan strukturalisme genetik dari Lucien Goldmann yang melihat aspek sejarah penciptaan, dan (6) mekanisme universal karya seni, termasuk sastra, yang sistemik, yang dihubungkan dengan perkembangan sosial (Junus, 1984: 3).

\section{Pendekatan Psikologi Sastra}

Menurut Ratna, secara defisi, tujuan psikologi sastra adalah memahami aspek-aspek kejiwaan yang terkandung dalam suatu karya sastra. Pada hakikatnya, karya sastra secara tidak langsung memberikan pemahaman kepada masyarakat, yakni pemahaman melalui tokoh-tokoh di dalam karya sastra tersebut. Pemahaman itu antara lain, sehubungan dengan psikologi tokoh-tokohnya, memahami unsur-unsur kejiwaan tokoh-tokoh fiksional dalam karya sastra. Sebagai dunia dalam kata, karya sastra memasukkan berbagai aspek kehidupan ke dalamnya, yakni aspek-aspek kemanusiaan yang diinvestasikan melalui tokohtokoh fiksional tersebut (Ratna, 2004: 341-344).

\section{Hakikat Pesan-pesan Kemanusiaan}

Menurut Nurgiantoro, pada hakikatnya manusia mana pun di atas dunia ini mempunyai nilai-nilai kemanusiaan yang universal, seperti prinsip moral, yang menyangkut etika (Nursal Luth,1990: 23-24). Menurut Yasser Arafat, nilai-nilai kemanusiaan adalah suatu hal yang dapat memanusiakan manusia atau bisa dikatakan juga kembali kepada fitrah manusia, dan itulah nilai-nilai kemanusiaan (Nursal Luth, 1990: 23-24). Karya sastra fiksi senantiasa menawarkan pesan moral yang berhubungan dengan sifat-sifat luhur kemanusiaan, memperjuangkan hak dan martabat manusia (Nurgiyantoro, 1995: 322).

\section{Kepedulian}

Cinta kepada sesama manusia dapat dilihat dari perlakuan seseorang kepada orang lain. Perlakuan yang baik kepada sesama manusia bukan dalam arti karena seseorang itu membela, menyetujui, mendukung, atau berguna bagi dirinya, melainkan datang dari hati nuraninya yang ikhlas disertai tujuan yang mulia. Menurut persepsi sosiologis, motivasi seseorang mencintai sesama manusia karena manusia itu tidak dapat hidup sendirian (K. Berterns, 2001: 170-174).

Menurut Suhendar dan Pien Supinah bahwa cinta terhadap sesama manusia berarti cinta dengan rasa persaudaraan. Rasa persaudaraan timbul bermula 
dari rasa belas kasihan yang tumbuh karena melihat orang lain menderita (M.E Suhendar dan Pien Supinah, 1993: 84).

\section{Kegotongroyongan}

Gotong royong merupakan aktivitas tolong menolong yang tampak dalam kehidupan bermasyarakat seperti (1) tolong menolong antartetangga yang saling berdekatan untuk pekerjaan-pekerjaan kecil di sekitar rumah dan pekarangan, (2) tolong menolong antarkaum kerabat untuk menyelenggarakan upacara-upacara adat atau hajatan, (3) aktivitas sopan santun tanpa pamrih untuk membantu secara spontan pada waktu seseorang penduduk desa mengalami kemalangan atau bencana (M.E Suhendar., Pien Supinah, 1993: 78).

\section{Toleransi}

Menurut Robert C. Solomon, ada suatu praktik budaya yang lebih umum yang diharapkan dihargai oleh setiap orang dalam suatu masyarakat. Praktik budaya itu adalah saling menghargai dan toleransi (Robert C Solomon, 1987: 103).

Toleransi adalah istilah yang digunakan dalam konteks sosial, kebudayaan dan, keagamaan untuk menggambarkan perilaku dan praktik-praktik yang melarang adanya perbedaan terhadap praktikpraktik atau anggota kelompok yang mungkin disetujui oleh mereka secara mayoritas. Sebaliknya, sikap tidak bertoleransi digunakan untuk menunjukkan adanya praktik diskriminasi yang dilarang

(Wikipedia.(http://en.wikipedia.org/wiki/Tolerance \#column-one\#column -one).

\section{Harapan}

Harapan dalam kehidupan manusia merupakan citacita, keinginan, penantian, kerinduan supaya sesuatu itu terjadi. Kepribadian yang kuat akan mengontrol harapan seefektif dan seefisien mungkin sehingga tidak merugikan bagi dirinya atau bagi orang lain, untuk masa kini atau untuk masa depan, bagi masa di dunia atau masa di akhirat kelak. Di samping itu harapan seseorang juga ditentukan oleh kiprah usaha atau bekerja kerasnya seseorang (Robert C Solomon,1987: 106107).

\section{Hakikat Dehumanisasi}

Dehumanisasi merupakan sebuah proses di mana anggota-anggota dari sekumpulan orang "merendahkan" kelompok lain dengan kegiatan yang tersembunyi atau terang-terangan atau dengan pernyataan. Dehumanisasi dapat dilakukan oleh sebuah organisasi (seperti negara) atau bagian dari perasaan individual dan aksi-aksi (Wikipedia, 2007). Tujuan dehumanisasi adalah membuat sekelompok orang yang dijadikan objek menjadi direndahkan.

\section{Interpretasi Teks}

Menurut Jan Van Luxemburg, interpretasi teks adalah cara membaca dan menjelaskan teks yang lebih sistematis dan lengkap (Jan van Luxemburg dkk (1991: 25). Untuk membaca dan menginterpretasikan tidak hanya didasari oleh latar belakang pengetahuan kesastraan. Latar belakang pengetahuan umum pun berperan, seperti pengetahuan bahasa, sejarah, geografi atau psikologi (Jan Van Luxemburg (dkk), 1991: 31).

Sebagian besar pendekatan yang bertujuan menginterpretasi bersifat hermeneuitis dalam arti kata bahwa tujuannya adalah memberi interpretasi yang lengkap dan pasti. Hermeneuitika adalah kensepsi interpretasi yang berasal dari ilmu tafsir kitab suci dan penjelasan teks sastra yang bertradisi panjang. Tujuannya adalah untuk memberikan penjelasan teks yang pasti dengan jalan menerapkan "lingkaran hermeneuitis", yaitu dengan menerangkan keseluruhan melalui bagian-bagian dan menerangkan bagian-bagian melaui keseluruhan (jadi semacam gerakan lingkaran) (Jan Van Luxemburg dkk, 1991: 44).

\section{METODOLOGI PENELITIAN}

Penelitian ini merupakan desk research, yaitu penelitian kepustakaan yang dilakukan di Jakarta yang rencananya berlangsung selama enam bulan, dari Juni 2011 sampai dengan Desember 2011. Penelitian ini menggunakan pendekatan kualitatif dengan metode analisis isi model induktif. Metode ini digunakan karena dianggap relevan untuk penelitian ini, dan tujuan, proses dan datanya termasuk acuan teori sastra yang melandasi analisisnya (pendekatan struktural genetik) yang mempunyai ciri-ciri kualitatif.

Dalam analisis isi kualitatif, seharusnya ditentukan apa bagian penarikan kesimpulan dari informasi yang dibuat, kepada aspek-aspek komunikator (pengalaman, pendapat dan perasaannya), kepada situasi hasil teks, kepada latar belakang sosial budaya, dan kepada teks itu sendiri atau efek dari 
pesan yang disampaikan. (Philipp Mayring, Qualitative Content Analysis, vol 1 no 2, (http://qualitativeresearch.org/fqs-texte/2-00/2-00mayring-e.htm\#g1\#g1, 2000)

Fokus penelitian ini adalah pesan-pesan kemanusiaan yang disampaikan oleh pengarang dalam novel Jenghis Khan, sedangkan subfokusnya adalah tinjauannya melalui kajian sastra dengan pendekatan struktural genetik, yaitu:

1. kajian struktural novel ditinjau dari sudut tokoh dan penokohan, latar, alur, tema dan amanat;

2. latar belakang sejarah dan sosial;

3. pandangan dunia pengarang;

4. pesan-pesan kemanusiaan dalam novel Jenghis Khan;

5. hubungan pesan-pesan kemanusiaan dalam novel Jenghis Khan dari aspek sosiologi sastra;

6. hubungan pesan-pesan kemanusiaan dalam novel Jenghis Khan dari aspek psikologi sastra.

Korpus data penelitian ini adalah novel berbahasa Inggris yang diterjemahkan dalam bahasa Indonesia karya John Man berjudul Jenghis Khan sebagai sumber data yang digunakan untuk informasiinfornasi data lainnya berupa referensi teori sastra, pendekatan struktural genetik, dan tulisan mengenai pengarang dan karya-karyanya.

Prosedur pengumpulan data dalam kegiatan penelitian terdiri dari 2 unsur, yaitu: (1) teknik pengumpulan data dan (2) instrumen pengumpulan data.

\section{Teknik Pengumpulan Data}

Dalam hal ini teknik pengumpulan data merupakan serangkaian perilaku atau tindakan yang digunakan peneliti untuk mengumpulkan seperangkat data, seperti wawancara dan observasi. Perilaku-perilaku ini merupakan suatu urutan yang dapat memberikan hasil, yaitu terkumpulnya data; sedangkan instrumen pengumpulan data mengacu pada suatu alat yang bersifat material yang digunakan untuk mengumpullkan data dan mencatatnya (Wiyoso Yodoseputro, 1994: 75-76).

Untuk melakukan penelitian ini, data yang dikumpulkan dilakukan dengan cara:

1. Melakukan pengecekan istilah khusus yang berhubungan dengan kebudayaan Cina dalam novel Jenghis Khan yang telah diterjemahkan ke dalam bahasa Indonesia;

2. membaca dan memahami isi ceritanya secara mendalam;

3. melakukan proses identifikasi masing-masing struktur novel, yaitu tokoh dan penokohan, latar, alur, tema dan amanat;
4. melakukan klasifikasi dengan menggolongkan kutipan-kutipan dalam novel yang mengandung pesan-pesan kemanusiaan, yaitu kepedulian, kegotong royongan, toleransi dan harapan;

5. mengadakan studi kepustakaan untuk mendapatkan data sekunder sebagai data pelengkap berupa sejarah, sosial budaya, sosiologi sastra, psikologi sastra, dan riwayat hidup pengarang untuk membantu pengklarifikasian data primernya, yaitu novel Jenghis Khan.

\section{Instrumen Pengumpulan Data}

Menurut Siswantoro, dunia penelitian, baik yang kualitatif maupun kuantitatif, sama-sama memerlukan instrumen. Dalam hal ini penelitian sastra yang merupakan penelitian kualitatif memiliki ciri individu (dengan sampel tunggal atau sedikit) dan merupakan studi kepustakaan atau studi teks. Untuk kondisi demikian, peneliti menggunakan instrumen yang relevan dengan medan yang dihadapi (Siswantoro, 2005: 65). Oleh karena itu, instrumen yang digunakan oleh penulis adalah teks novel yang berfungsi sebagai sumber data.

Untuk memanfaatkan dokumen yang padat isi biasanya digunakan teknik tertentu. Teknik yang paling umum digunakan ialah content analysis atau dinamakan "kajian isi". Holsti (dalam Guba dan Lincoln, 1981:240) menyatakan bahwa kajian isi adalah teknik yang digunakan untuk menarik kesimpulan melalui usaha menemukan karakteristik pesan, dan dilakukan secara objektif dan sistematis (Moleong,2004: 163).

Penelitian yang dilakukan untuk menganalisis novel Jenghis Khan mengikuti aturan langkahlangkah analisis data berdasarkan teori-teori pengkajian novel dan pendekatan struktural genetik, sebagai berikut:

1. menerjemahkan novel Jenghis Khan yang ditulis dalam bahasa Inggris ke dalam bahasa Indonesia;

2. membaca dan memahami isi ceritanya secara mendalam;

3. menetapkan kriteria analisis untuk struktural novel dan pesan-pesan kemanusiaan;

4. menganalisis data dengan teknik pencatatan yang dilakukan dengan cara memasukkannya ke dalam tabel kerja (tabel 1);

5. membuat deskripsi hasil analisis data yang telah diolah;

6. melakukan pembahasan hasil penelitian; 
7. menarik kesimpulan berdasarkan fokus, subfokus dan tujuan penelitian;

8. melaporkan hasil penelitian dalam bentuk jurnal.

\section{TEMUAN DAN PEMBAHASAN HASIL PENELITIAN}

\section{Deskripsi Data Pesan-pesan Kemanusiaan}

Berikut adalah deskripsi data Data Pesan-pesan Kemanusiaan yang dihubungkan dengan latar belakang sosial budaya.

\section{Kepedulian}

Latar belakang sosial budaya yang melatari penulisan novel Jenghis Khan adalah kondisi masyarakat Mongol yang pada waktu itu mengalami ketidak- kepastian untuk hidup dan suku di antara mereka saling berpencar, tidak bersatu.

John Man dalam kelompok masyarakat dari kalangan yang berbeda ingin mengungkapkan bahwa tanggapan dari sebagian masyarakat tidak sepenuhnya benar tentang Jenghis Khan. Oleh karena itu, melalui novelnya, John Man menyampaikan pesan bahwa Jenghis Khan pun punya rasa peduli, terutama pada masyarakat Mongol. Martabat manusia dapat dijaga dengan sikap peduli antar sesama manusia. Untuk itu, setiap orang khususnya para generasi muda, hendaknya dapat mengubah sikap tinggi hati dan semena-mena terhadap sesamanya, manusia akan menempatkan manusia lain dengan semestinya.

Jenghis Khan juga mempunyai hati yang perduli terhadap rakyat kecil, dia telah membunuh atau menangkap pejabat-pejabat tersebut tetapi Jenghis Khan melepaskan "kelinci" (rakyat kecil atau rakyat biasa) karena Jenghis Khan beranggapan rakyat tidak bersalah dan tidak berbahaya dalam melebarkan kekuasaannya.

a. Hubungan dengan Latar Sosial Budaya

Menurut kepercayaan masyarakat Mongol pada jaman tersebut mereka sangat percaya dengan adanya sult atau anjing-anjing langit. Jenghis Khan sebagai keturunan sang Dewa harus menjaga anjing-anjing langit sebagai lambang kepercayaan nya dan juga kepercayaan bangsa Mongol sebagai pelindung mereka. b. Hubungan dengan Latar Psikologis

Jenghis Khan, yang dikenal sebagai pembunuh darah dingin, membunuh tanpa ampun, yang selalu menjadi momok para lawannya, ternyata dibalik itu semua Jenghis Khan adalah seorang yang mempunyai kepedulian yang sangat tinggi terutama pada rakyat kecil, baik terhadap rakyat Mongol ataupun rakyat kecil di bangsa musuh atau bangsa yang dia jajah. Hal ini dilakukan agar rakyat mendapatkan rasa aman, bebas, dan dapat terus hidup dengan makmur.

\section{Kegotongroyongan}

Saat masih kanak-kanak Jenghis Khan suka berburu dengan saudara-saudaranya. Tanpa tidak sengaja ternyata para pencuri sudah mengetahui tempat persembunyian kuda-kuda klan nya. Karena masih sangat muda, Jenghis Khan dengan saudara lainnya hanya terdiam dan menunggu saat yang tepat untuk membebaskan kuda-kuda tersebut. Temujin (Jenghis Khan) sebagai saudara tertua mempunyai tanggung jawab yang besar dalam menemukan kuda-kuda tersebut. Semua itu juga didorong sifat kegotongroyongan pada saudarasaudaranya. Niatnya yang tulus dalam pencarian tersebut membuat para saudaranya sungkan terhadap Temujin karena dia melakukannya seorang diri dengan melewati padang rumput selama berhari-hari dengan gagah berani dan tanpa rasa takut Temujin mencari jejak kuda tersebut sampai dapat.

\section{a. Hubungan dengan Latar Sosial Budaya}

Latar sosial budaya novel ini adalah sebelum berdirinya dinasti di Cina, bangsa Mongol masih terpecah-pecah dan belum bersatu, bangsa lain pun saling memperebutkan kekuasaannya. Daerah pedesaan Mongol pada masa Jenghis adalah dunia ger dan kuda. Kuda dilatih, sedangkan unta diberi beban muatan untuk membawa barang-barang. Alam dan masa pada saat itu sangat jauh dengan adanya modrensasi. Transportasi yang ada pada jaman tersebut adalah kuda. Kuda merupakan alat transportasi yang sangat penting. Tanpa kuda mereka tidak dapat berpergian jarak jauh, tidak dapat mengunjungi klan satu ke klan yang lain, juga yang paling penting tidak dapat menyatukan bangsa Mongol.

b. Hubungan dengan Latar Psikologis

Secara psikologis, seorang istri telah diculik oleh orang lain merupakan pukulan yang sangat berat bagi seorang lelaki, dan merupakan suatu yang sangat memalukan karena jika istri diculik dan dilecehkan oleh orang lain (penjahat), suami pasti 
akan merasa dirinya pun ikut dilecehkan. Apalagi jika seorang istri diculik oleh orang yang kita kenal. Ini terjadi pada Jenghis Khan. Borte yang telah diculik oleh bangsa Merkit, membuat Jenghis Khan marah besar dan tidak mengampuni bangsa Merkit terutama orang-orang yang telah merencanakan penculikan ini. Bangsa Merkit mempunyai dendam tersendiri pada ayah Jenghis Khan dan ini dilampiaskannya melalui Jenghis Khan. Dengan pertolongan dan kegotongroyongan dari saudara ataupun teman-teman Jenghis Khan, semua dapat dilalui dengan lancar.

\section{Toleransi}

Dalam novel ini banyak terdapat gambaran tentang adanya tidak keseimbangan hubungan sosial antarmasyarakat. Dalam novel ini, pengarang menyampaikan kepada masyarakat bahwa status sosial lebih tinggi yang biasanya berasal dari golongan pejuang, atau orang-orang angkatan bersenjata. Seharusnya mereka dari golongan yang sama bisa lebih memiliki sikap toleransi yang tinggi dan saling membantu.

Saat mengadakan perang Jenghis Khan sebenarnya juga terpikirkan untuk berdamai dengan negaranegara tersebut, salah satunya adalah bangsa Tangut. Jenghis Khan memberikan bangsa Tangut untuk mempertimbangkannya demi menyelamatkan bangsanya dari peperangan karena bagaimanapun juga jika suatu bangsa berperang yang menderita pasti yang pertama adalah rakyatnya. Di dalam hati Jenghis Khan yang penuh ambisi terbukti masih memikirkan, perduli, dan mempunyai rasa toleransi yang tinggi terhadap rakyat biasa.

a. Hubungan dengan Latar Sosial Budaya

Bangsa Cina maupun Mongol merupakan negara yang saling berdekatan, baik dari kebudayaan, kepercayaan, dan sejarah pun saling berkaitan. Salah satunya adalah kepercayaan. Pada masa Jenghis Khan kepercayaan yang muncul adalah Taoisme. Taoisme (Tionghoa: 道教 atau 道家) juga dikenal dengan Daoisme, diprakarsai oleh Laozi (老子;pinyin:Lăož) sejak akhir Zaman

Chunqiu yang hidup pada 604-517 sM atau abad ke-6 sebelum Masehi. Taoisme merupakan ajaran Laozi yang berdasarkan Daode Jing (道德經,pinyin:Dàodé Jīng). Pengikut Laozi yang terkenal adalah Zhuangzi (莊子) yang merupakan tokoh penulis kitab yang

berjudul Zhuangzi.

Taoisme adalah sebuah aliran filsafat yang berasal dari Cina, dan telah menyebar sampai ke Mongol. Taoisme sudah berumur ribuan tahun, dan akarakar pemikirannya telah ada sebelum masa Konfusiusme. Hal ini dapat disebut sebagai tahap awal dari Taoisme. Bentuk Taoisme yang lebih sistematis dan berupa aliran filsafat muncul kirakira 3 abad SM. Selain aliran filsafat, Taoisme juga muncul dalam bentuk agama rakyat, yang mulai berkembang 2 abad setelah perkembangan filsafat Taoisme.

b. Hubungan dengan Latar Psikologis

Perubahan sifat yang lebih baik dari seorang Jenghis Khan merupakan sesuatu yang sangat dinantikan oleh para rakyat dan pengikutnya, karena menurut pandangan Taoisme, hidup manusia sudah digariskan oleh 'langit'. Manusia sudah memiliki jalannya masing-masing. Yang harus dilakukan manusia hanya meneliti jalan itu dan mengikuti jejak itu tanpa mencoba memaksakan pandangannya yang sempit, serta tanpa kehendak ingin menyelewangkan diri dari yang alamiah demi keuntungan pribadi. Jika manusia telah berhasil mengikuti jalan Dao, maka ia tidak perlu takut akan kematian. Kematian adalah sebuah proses alam dan manusia tidak dapat melawan alam, oleh karena itu manusia tidak perlu taku atau cemas terhadap kematian. Kematian hanya mengembalikan manusia kepada Dao (Bagus Takwin. 2003: 8).

Dengan pengertian, pemahanan dan pengajaran ajaran Taoisme, Jenghis Khan dapat hidup lebih baik, bijaksana, dan dapat menerima hidup ini dengan apa adanya. Ambisinya pun lama-lama pudar seiring dengan perkembangan ajaran Taoisme yang dia pelajari.

\section{Harapan}

Masyarakat Mongol secara garis besar memiliki semangat pantang menyerah. Mereka tidak takut dengan cobaan dan kesusahaan, bahkan sanggup berhadapan dengan segala cobaan demi mencapai tujuannya. Mereka juga teguh menjaga harga diri dan kehormatan bangsa.

Oleh karena itu, John Man, sebagai pengarang dari novel Jenghis Khan ini, mengharapkan agar manusia dapat belajar dari pengalaman sejarah masa lalu dan berusaha dengan keras membangun 
kondisi yang lebih baik. Selain itu, ia mengharapkan agar manusia dapat bersikap lebih bijak pada waktu mengatasi segala masalah dan penderitaan dan menyakini bahwa kehidupan yang penuh penderitaan bahkan dapat menjadi inspirasi penting menuju hidup yang lebih bermakna.

Harapan Jenghis Khan yang utama adalah menyatukan Mongol, karena Mongol pada masa tersebut berasal dari klan yang berbeda, saling berperang demi sebuah kekuasaan dan kekayaan klannya sendiri. Tetapi tidak dengan Jenghis Khan. Dia berperang dengan bangsa lain untuk mencari kekuasaan lain, yang membuat pandangan klan lainnya berpikir bahwa Jenghis Khan begitu kuat. Pada akhirnya tanpa ada peperangan dengan klan sebangsanya, mereka sendiri masuk dan bergabung dengan Jenghis Khan dalam berperang dengan bangsa lain, salah satunya adalah Cina.

a. Hubungan dengan Latar Sosial Budaya

Mongol pada masa Jenghis Khan merupakan suatu masyarakat yang nomaden, semua berkumpul pada klannya sendiri dan pergi dari tempat satu ke tempat yang lain untuk mendapatkan rasa nyaman dan penghidupan yang tenteram. Tetapi lahirnya Jenghis Khan telah membuat perubahan baru pada bangsa Mongol, yaitu bersatunya klan atau rakyat Mongol. Bukan hanya itu saja bahkan Mongol telah menjadi negara yang disegani oleh kalangan bangsa lain, khususnya Cina, karena Cina negara yang berbatasan langsung dengan Mongol dan berdirinya dinasti di Cina berawal dari masa Jenghis Khan. Menurut rakyat Mongol lahirnya dinasti pertama kali di Cina secara tidak langsung merupakan dampak yang ditimbulkan oleh Jenghis Khan.

b. Hubungan dengan Latar Psikologis

Setelah Mongol bersatu, klan atau rakyat di Mongol menjadi menetap di satu tempat, tidak lagi nomaden seperti dulu. Rakyat Mongol lebih mempunyai rasa kesatuan yang utuh tidak lagi berpecah belah. Jenghis Khan menjadi bapak bangsa bagi rakyat Mongol. Karena dialah Mongol menjadi satu, makmur, dan berkembang sampai sekarang. Bukan hanya Mongol, tetapi bangsa Cina juga menghormatinya sebagai pendiri dinasti dan di kedua negara tersebut para pemuja mencari berkahnya.
Tabel 1 Presentasi Penelitian Aspek Pesan-pesan Kemanusiaan Novel Jenghis Khan Karya John Man

\begin{tabular}{|c|c|c|c|}
\hline No & Aspek Analisis & Jumlah & Presentasi \\
\hline 1 & Kepedulian & 5 & $31 \%$ \\
\hline 2 & Kegotongroyongan & 3 & $19 \%$ \\
\hline 3 & Toleransi & 5 & $31 \%$ \\
\hline 4 & Harapan & 3 & $19 \%$ \\
\hline & Jumlah & 16 & $100 \%$ \\
\hline
\end{tabular}

Berdasarkan Table 1 dapat diketahui bahwa dalam Novel Jenghis Khan Karya John Man terdapat 16 informasi yang menunjukkan nilai-nilai kemanusiaan sang tokoh terhadap pesan-pesan kemanusiaan, kepedulian dan toleransi berjumlah 5 dengan presentasi $31 \%$, kegotongroyongan dan harapan berjumlah 3 dengan presentasi 19\%.

\section{Hubungan antara Pesan-Pesan Kemanusiaan dalam Novel Jenghis Khan dengan Latar Sosial Budaya}

Sastra sebagai gambaran masyarakat bukan berarti karya sastra tersebut menggambarkan keseluruhan warna dan rupa masyarakat yang ada pada masa tertentu dengan permasalahan tertentu pula. Novel merupakan salah satu di antara bentuk sastra yang paling peka terhadap cerminan masyarakat. Menurut Johnson (Faruk, 2005: 45-46), novel mempresentasikan suatu gambaran yang jauh lebih realistik mengenai kehidupan sosial. Ruang lingkup novel sangat memungkinkan untuk melukiskan situasi lewat kejadian atau peristiwa yang dijalin oleh pengarang atau melalui tokoh-tokohnya. Kenyataan dunia seakan-akan terekam dalam novel, berarti ia seperti kenyataan hidup yang sebenarnya.

Dalam novel Jenghis Khan, John Man mengungkapkan bahwa Jenghis Khan benar-benar berjasa dalam menyatukan dan memakmurkan bangsa Mongol. Masyarakat Mongol menjadi bersatu dan hidup menetap di satu tempat. 


\section{Hubungan antara Pesan-Pesan Kemanusiaan dalam Novel Jenghis Khan dengan Latar Psikologis}

Siswantoro (2004: 31-32) menyatakan bahwa secara kategori, sastra berbeda dengan psikologi, sebab sastra berhubungan dengan dunia fiksi, drama, puisi, dan esay yang diklasifikasikan ke dalam seni (art), sedangkan psikologi merujuk kepada studi ilmiah tentang perilaku manusia dan proses mental. Meski berbeda, keduanya memiliki titik temu atau kesamaan, yakni keduanya berangkat dari manusia dan kehidupan sebagai sumber kajian. Bicara tentang manusia, psikologi jelas terlibat erat, karena psikologi mempelajari perilaku. Perilaku manusia tidak lepas dari aspek kehidupan yang membungkusnya dan mewarnai perilakunya. Psikologi sastra mempelajari fenomena, kejiwaan tertentu yang dialami oleh tokoh utama dalam karya sastra ketika merespon atau bereaksi terhadap diri dan lingkunganya. Dengan demikian, gejala kejiwaaan dapat terungkap lewat perilaku tokoh dalam sebuah karya sastra.

Dalam novel Jenghis Khan, John Man mengungkapkan secara jelas bahwa semua yang dilakukan Jenghis Khan adalah demi kemakmuran dan kesatuan di daerah Mongol. Dengan begitu rakyat Mongol dikenal di seluruh dunia dan menjadi negara yang kuat di masanya. Selain itu juga Jenghis Khan setelah bertemu dengan sang Guru yang berasal dari Cina membawa suatu ajaran Taoisme, yang menjadikan Jenghis Khan mempunyai pandangan hidup yang berbeda dan lebih baik, Jenghis Khan juga menganjurkan pada masyarakat Mongol untuk mempelajari dan mengamalkan ajaran Taoisme.

\section{Keterbatasan Penelitian}

Peneliti telah berusaha melakukan penelitian novel Jenghis Khan karya John Man semaksimal mungkin, akan tetapi tetap ada beberapa keterbatasan peneliti.

1. Pesan-pesan kemanusiaan dalam novel yang dikaji oleh peneliti hanya ditinjau dari pesanpesan kepedulian, kegotongroyongan, toleransi, harapan, hubungan pesan-pesan kemanusiaan dengan latar sosial budaya dan hubungan pesan-pesan kemanusiaan dengan latar psikologi. walaupun masih banyak segi kemanusiaan yang dapat dikaji. Dan pendekatan yang digunakan adalah kajian struktural genetik. Memang akan lebih baik apabila topik yang diangkat lebih dapat dikembangkan dan diteliti melalui ruang lingkup bidang yang lebih luas, misalnya filsafat.

2. Peneliti memiliki keterbatasan teori sastra serta teori-teori yang berkaitan dengan segi kemanusiaan.

\section{KESEIMPULAN DAN SARAN}

\section{Kesimpulan}

Berdasarkan hasil analisis dan deskripsi penelitian yang telah dilakukan oleh peneliti, ada beberapa kesimpulan yang dapat dikemukakan dalam bab ini. Kesimpulan ini pada dasarnya secara khusus memfokuskan pada pesan-pesan kemanusiaan dalam novel Jenghis Khan karya John Man.

Pesan-pesan kemanusiaan yang meliputi kepedulian, kegotongroyongan, toleransi dan harapan disampaikan kepada para pembaca, baik kepada masyarakat umum pencinta karya sastra maupun kepada pembaca dari lingkungan akademik. Pesan-pesan kemanusiaan disampaikan oleh pengarangnya melalui unsur-unsur pembangunan novel, yaitu unsur intrinsik, dan kajian struktural genetik yang meliputi latar belakang sejarah, sosial budaya serta pandangan dunia pengarang seperti yang telah disebut di atas dan pandangan masyarakat Mongol.

Pesan-pesan kemanusiaan dalam novel ini layak dikaji karena sangat bermanfaat dalam meningkatkan pendidikan moral para pembaca khususnya generasi muda.

\section{Saran}

Berdasarkan kesimpulan penelitian berikut di atas, penulis ingin turut memberikan kontribusi dalam bentuk saran sebagai berikut:

Melalui penelitian novel Jenghis Khan ini, pengajar diharapkan dapat membimbing pelajar atau mahasiswa menemukan pesan-pesan kemanusiaan yang terdapat di dalamnya. Sekaligus memahami dan mendalami latar belakang sejarah, sosial budaya, sosilogi sastra dan psikologi sastra yang digunakan oleh pengarangnya dalam penulisan novelnya. Dengan memahami pesan-pesan kemanusiaan serta latar belakang timbulnya pesanpesan tersebut, para pelajar atau mahasiswa dapat lebih meningkatkan rasa kepekaannya terhadap nilai-nilai kemanusiaan yang selalu ada di setiap jaman. 


\section{DAFTAR PUSTAKA}

Buku:

[1] Andreas Teeuw. 1984. Sastra dan Ilmu Sastra, Pengantar Teori Sastra. Jakarta: Pustaka Jaya.

[2] Aminuddin. 1987. Pengantar Apresiasi Karya Sastra. Bandung: Sinar Baru.

[3] Burhan Nurgiyantoro. 1995. Teori Pengkajian Fiksi. Yogyakarta: Gadjah Mada University Press.

[4] Imam Syafie. 1990. Penerapan Cara Belajar Siswa Aktif (CBSA) Dalam Pengajaran Sastra, Sekitar Masalah Sastra.

Malang: Yayasan Asih Asah Asuh.

[5] Jan Van Luxemburg, dkk. 1991. Tentang Sastra. Jakarta: Intermasa.

[6] James H. Pickering dan Jeffry D. Hoeper. 1981. Concise Companion to Literature. New York: Macmillan Publishing.

[7] Jacob Sumardjo dan Saini KM. 1986. Apresiasi Kesusastraan. Jakarta: Gramedia.

[8] John Man. Jenghis Khan. 2008. Legenda Sang Penakluk dari Mongolia. Jakarta: Alvabet.

[9] Lucien Goldmann. 1977. Towards A Sociology of The Novel. London: Tavistock Publication.

[10] MH. Abrams. 1971. A Glossary of Literary Term. New York: Holt Rinehart, Inc.
[11] Robert Stanton. 2007. Teori Fiksi. Yogyakarta: Pustaka Pelajar.

[12] Rene Wellek dan Austin Warren. 1989. Teori Kesusastraan. Jakarta: Gramedia.

[13] Siswantoro. 2005. Metodologi Penelitian Sastra: Analisis Psikologi. Surakarta: Muhammadiyah University Press.

[14] Suwardi Endraswara. 2003. Metodologi Penelitian Sastra: Epistemologi, Model, Teori, dan Aplikasi. Yogyakarta: FBS Universitas Negri Yogyakarta.

[15] Umar Junus. 1986. Sosiologi Sastra, Persoalan Teori dan Metode. Kuala Lumpur: Dewan Bahasa dan Pustaka.

Internet:

[16] http://www.bukabuku.com/authorscorner/det ail/2012/john-man.html.

[17] Wikipedia.(http://en.wikipedia.org/wiki/Toler ance\#column-one\#column-one)

[18] Michelle Maiese. What is Means to Dehumanize. 2003.

(http://www.beyondintractibility.org/action/a uthor.jsp).

[19] Philipp Mayring. Qualitative Content Analysis. $2000 \quad$ (http://qualitativeresearch.org/fqs-texte/2-00/2-00mayringe.htm\#g1\#g1). 